\title{
Tekmeria
}

Vol 14 (2018)

$(2017-2018)$

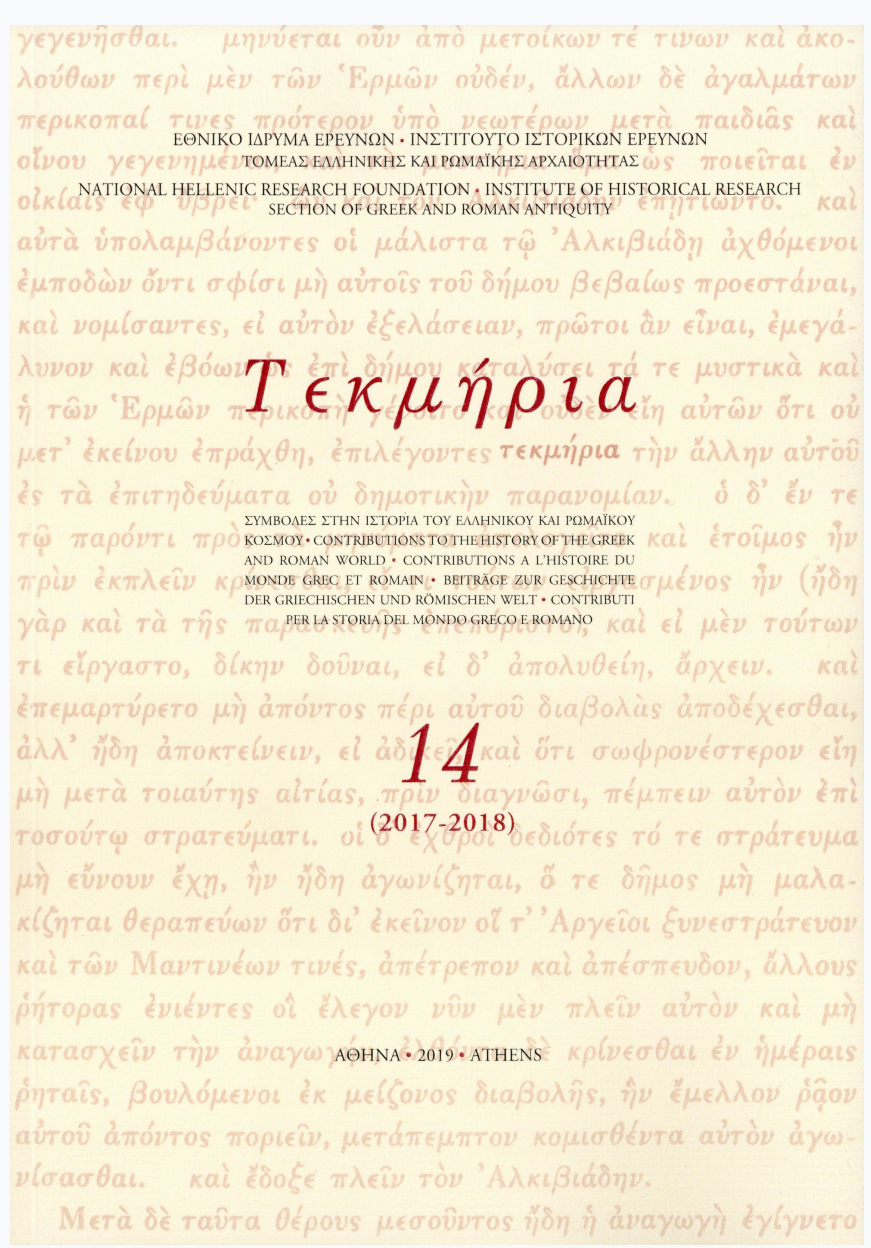

\section{Notes on a Gladiatorial Inscription from Plotinopolis}

Dimitrios Papanikolaou

doi: $10.12681 /$ tekmeria.20419

Copyright (C) 2019, Dimitrios Papanikolaou

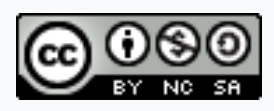

This work is licensed under a Creative Commons Attribution-NonCommercialShareAlike 4.0.

\section{To cite this article:}

Papanikolaou, D. (2019). Notes on a Gladiatorial Inscription from Plotinopolis. Tekmeria, 14, 203-213.

https://doi.org/10.12681/tekmeria.20419 


\section{DIMITRIOS PAPANIKOLAOU}

\section{Notes on a Gladiatorial Inscription from Plotinopolis}

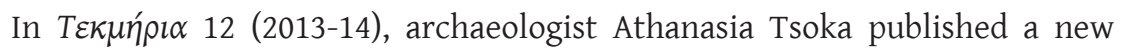
gladiatorial tombstone from Plotinopolis. ${ }^{1}$ The inscribed tombstone, which bears the image of a gladiator, was found in 2001 by locals $750 \mathrm{~m}$ southwest of the Didymoteicho Train Station. The find was handed over to the Archaeological Museum of Komotini (Kopornví), where it is still deposited with inventory number АГК 12373; ${ }^{2}$ the stone was eventually published by Athanasia Tsoka (see n. 1). The aim of this paper is to examine certain textual and linguistic issues that the inscription raises; the elucidation of those points will not only shed light to the text of the inscription itself, but it will also offer new insights into the use of the Greek language in this Greek gladiatorial inscription of the Roman imperial era.

According to Tsoka, the text of the inscription runs as follows: ${ }^{3}$

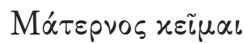

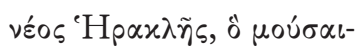

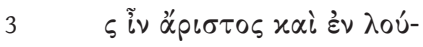

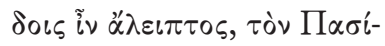

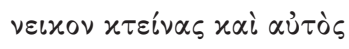

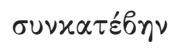

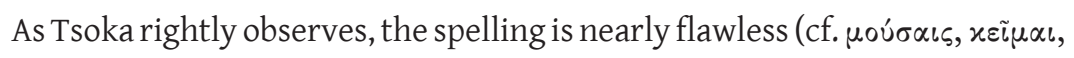
ád $\varepsilon i \pi \tau \circ \varsigma, x \tau \varepsilon i v a \varsigma$ etc.); the only point of divergence from the rules of Greek orthography is (according to Tsoka) the twice repeated verb form iv (1l. 3-4), that Tsoka regards as the first singular of the Imperfect tense of the verb si $u i$. She contends that the word is written $\tilde{i \nu}$ (instead of the correct $\tilde{\eta} v$ ) because of a supposed influence of the linguistic phenomenon of iotacism. ${ }^{4}$ The main

\footnotetext{
1. Tsoka 2015.

2. On the discovery of the inscription, see Tsoka 2015, 81 n. 1 .

3. Tsoka 2015, 86.

4. Tsoka 2015, 86.
} 
question that arises is why the scribe might have made a mistake misguided by iotacism in this case, when he did not do so in the case of other Greek words, for example in words such as $x \varepsilon i \tilde{\mu} \alpha \iota, \ddot{\alpha} \lambda \varepsilon \iota \pi \tau \circ \varsigma$ or $x \tau \varepsilon i v \alpha \varsigma$, which Imperial-Era Greek scribes tended to spell incorrectly. A further point of disagreement with Tsoka's argument is the second omicron in 1.2. Since Tsoka has regarded ĩv as the verb of a wider clause, this omicron was taken to be the (rare Homeric?) masculine singular of a relative pronoun which usually introduces a relative clause $\left({ }^{\circ}\right) .^{5}$ This type of analysis introduces two (most probably unnecessary) relative clauses into this very short inscription.

According to my view, these textual problems are solved, if we adopt the latest proposal of Nicolay Sharankov on the Plotinopolis text. ${ }^{6}$ The proposal rightly assumes that (a) the second omicron in 1.2 is the masculine Greek article in the singular nominative $(\delta)$, which is dependent on the following

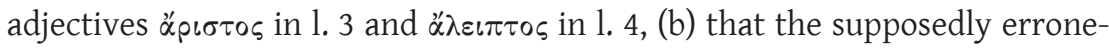
ous form ĩv in lines 3 and 4 is simply the ending of a poetic dative (Moú $\sigma \alpha \iota \sigma \iota v$,

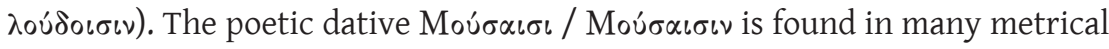
Greek inscriptions of the Roman Imperial Era, especially in inscriptions of a poetical or quasi-poetical nature (mostly epitaphs of erudite persons); ${ }^{7}$ it is

5. This rarer Homeric Greek form of the masculine of the relative pronoun (= who) was spelt $\delta$ (without $\vdots \xi \varepsilon i \alpha$ ): see Autenrieth 1895, 202, meaning 3.

6. I refer here to the proposal introduced by Sharankov in brackets in the midst of an entry, which otherwise reproduces Tsoka's text, see AnnÉpigr 2014 (2nd ed.) no. 1165 (p. 493). The only parallel texts that Sharankov cites, in order to support his view, is IK Hadrianoi/Hadrianeia 173 (the closest parallel to the Plotinopolis text, see n. 7) and the totally irrelevant SEG 35, 640. In my view, Sharankov's proposal should gain in prominence, since it provides the only viable reading of the text of this gladiatorial inscription (see discussion later on).

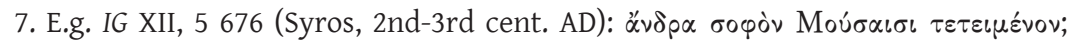

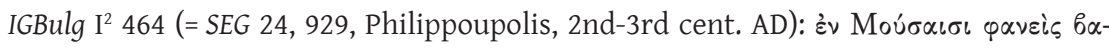
$\sigma \iota \lambda \varepsilon^{\prime} \varsigma$ (cf. also IGBulg III 1 1024, on a female musician); GIBM 539 (= IK Ephesos 1539; Keil,

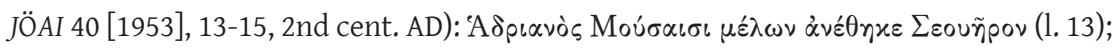

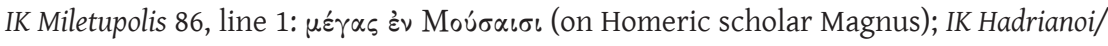

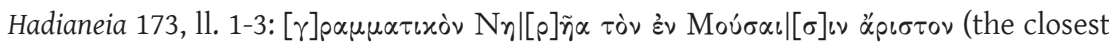

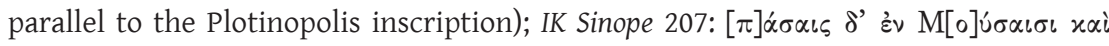

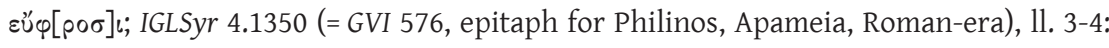


also a very common form in Greek literary epigrams of the Hellenistic and Roman times preserved in the Anthologia Palatina. ${ }^{8}$ This poetic dative is not absent from prose inscriptions either. ${ }^{9}$

Its presence in this passage of the Plotinopolis inscription of gladiator Maternos would be unsurprising, given the fact that the writer of the text wants to comment on the education of the deceased gladiator (possibly involving also

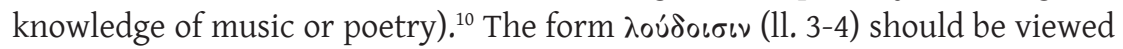

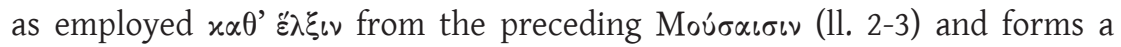
grammatically correct poetic form of an Ionian/Attic dative (see n. 9).

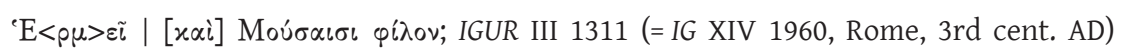

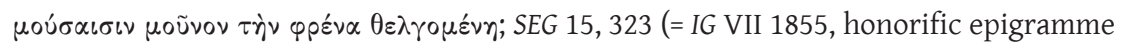
for Cervonius, proconsul of Achaea, found at Thespiae, first half of 4th cent. AD), 1. 1:

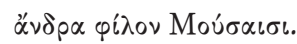

8. The poetic dative Mov́ $\alpha_{\iota} \sigma \iota(\nu)$ is found in Nossis, poetress of the $3 \mathrm{rd}$ cent. BC (AP 7.718, v. 3: Mov́ $\alpha \iota \sigma \iota \varphi \hat{\imath} \lambda \alpha$, speaking of herself), and in Antipater of Sidon, epigramma-

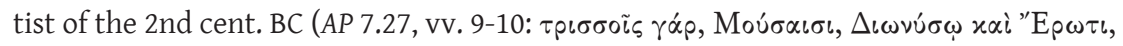

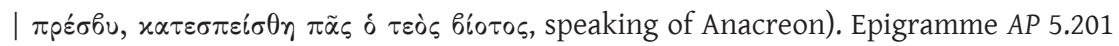

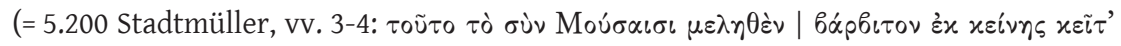
हैंน $\pi \alpha v v u \chi(\delta \circ \varsigma)$, of unknown date, should be dated before $100 \mathrm{BC}$, since it belongs to a segment of the Palatine Anthology (5.134-215) that originally formed part of the

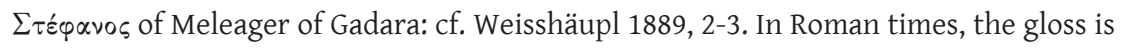
found in Antiphilus of Byzantium, poet of the first century AD (AP 9.192, v. 7: ' $\lambda \lambda \alpha \tau \varepsilon \sigma \dot{\nu} \nu$

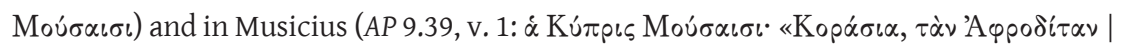
$\left.\tau \iota \mu \tilde{\alpha} \tau^{\prime}[\ldots]\right)$, an otherwise unknown poet of probable Roman date. It is also found in the epigrammes of Gregory of Nazianzos, composed in the second half of the 4th cent. AD:

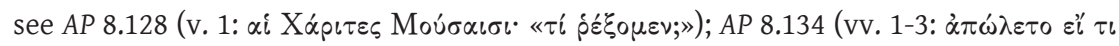

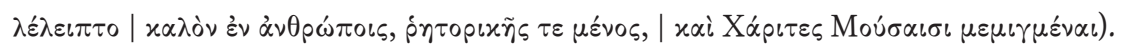
See also the epideictic epigramme preserved by Stephanus of Byzantium ('E $\theta v \iota x \alpha$, s.v.

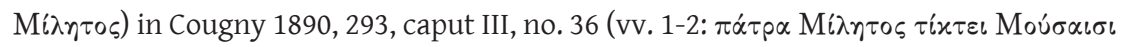

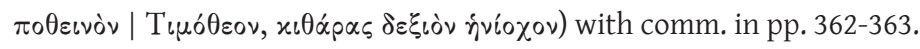

9. E.g. SEG 32, 1269 (votive inscription from Phrygia, Roman imperial period): $̇ x$

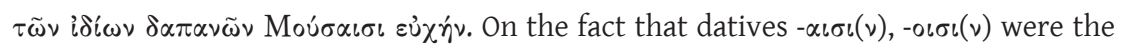
poetic alternatives of the mainstream Attic datives - $\alpha\llcorner 5,-0,5$ of the first and second Attic declension, see Smyth 1956, 49, 54.

10. On the objective of the passage to exalt Maternos' erudition when alive, see also Tsoka 2015, 87, 89-90. 
Given the above considerations, Sharankov's proposal (see n. 6) offers the only viable text for the Plotinopolis inscription, which (in fact) should be read as follows:

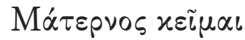

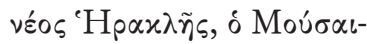

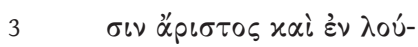

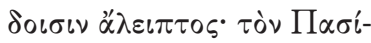

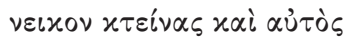

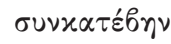

The new proposal for the Plotinopolis text, which could be verified by an inspection of the photographs of the inscription ${ }^{11}$ not only restores the totally flawless orthography of the inscription, but it also retains the meaning already known from Tsoka's paper (see n. 1): "I, Maternos, lie here, the new Hercules, the excellent in the Muses (= letters, fine arts, poetry) and invincible in the games; after I killed Pasineikos, I also went down [to Hades] together with him". By and large, the inscription (a prose text of a particularly poetic flavour) speaks of an erudite man, who became a gladiator under circumstances unknown to us; this man died during the mortal combat against gladiator Pasineikos, which took place in the gladiatorial arena of Plotinopolis (later 2nd to early 3 rd cent. AD).

The last point to be discussed in this paper is concerned with the word $\lambda \circ \tilde{\delta} \delta \circ$, which appears in the inscription in dative plural (1l. 3-4). Tsoka be-

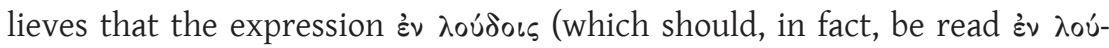

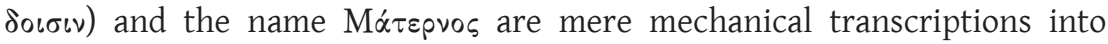
Greek letters of the Latin words ludi, Maternus. ${ }^{12}$ I wish to express my slight disagreement over this approach. First of all, the presence of a Latin-derived name in the Greek-speaking East of the Roman Empire, does not necessarily imply transcription - not to mention that it does not always reveal much about ethnic identity, or the degree of someone's Romanisation / Hellenisation. ${ }^{13}$ In the cosmopolitan Greco-Roman ecumene of the first four centuries

11. For photographs of the inscription, see Tsoka 2015, 96-98.

12. Tsoka 2015, 86 (in the critical apparatus), 87, 90.

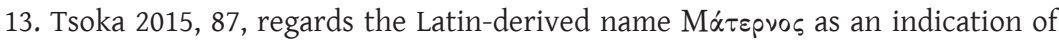
Roman descent or cultural Romanisation on the part of this gladiator. 
$\mathrm{AD}$, a Greek-speaking person, even one boasting of Hellenic erudition, could well bear a Latin-derived name (e.g. $\Phi \alpha b \omega$ pivos and $\Lambda \circ \lambda \lambda \iota \alpha \nu \grave{s}$ the sophists,

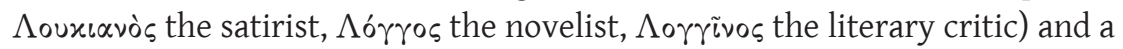
Latin-speaking person living in the western half of the Empire could well hold a Greek-derived name. In Late Antiquity, one could well be called Ambrosius, Hieronymus, Boethius, and still be a master of Latin prose and belles lettres. ${ }^{14}$

As far as the world of gladiation in the Eastern part of the Roman Empire is concerned, a Latin-derived name is definitely not a safe marker of Roman identity or Romanisation. Greek gladiatorial inscriptions provide us with sufficient evidence demonstrating the habit of Greek-speaking gladiators to adopt a professional pseudonym, in many cases (25\% of all recorded cases) a Latin-derived one..$^{15}$ The Latin-derived pseudonym seems to have implied tacit recognition of the fact that the gladiator (and his audience) considered himself to be fighting within the framework of a recognisably Roman or Roman-

14. This should not be meant to be a rejection of the fact that there was considerable cultural and linguistic contact between the Greek- and Latin-speaking worlds during the 3rd cent. AD. In fact, in this century we find the first serious pieces of evidence that significant numbers of Greek speakers try to learn Latin: on the evidence from Egypt, see bibliography in Cameron 1973, 89 n. 1. In the Latin West, Greek did not only continue to be the second language taught at the Roman imperial educational system, but it also acquired the status of the "language of revelation" among pagan/Hermetic and Christian circles alike: see, for instance, the remarks of Carcopino 1942, 285, on Greek as "le langage obligatoire de la révélation" in later antiquity, a perception which has influenced the important discussion of Athanassiadi 1999, 18-20 with nn. 24-25. Through my above discussion, I just wish to lay doubts upon the perception that, since someone's name is $b$-derived, therefore this person has $b$ ethnic identity or has abandoned culture $a$ for culture $b$. In my view, this is highly problematical when we talk about the globalised late Roman world. If foreign names can say something about this world, this has to do with the degree of cosmopolitanism and the openness of a society/region to the outside world and to the culture of the Other. On the frequent anti-Roman statements of Lucian for instance (a literatus with a Latin-derived name), see Swain 1996, 316-321, 329; Whitmarsh 2001, 247-280. On Longinus' Greek identity as opposed to the Roman one of the addresee of his work, see Whitmarsh 2001, 66-69.

15. On the well-attested habit of Greek-speaking gladiators to adopt pseudonyms (sometimes at the instigation of their superiors), see Robert 1940, 297-301; Carter 1999, 265-266; Nigdelis, Stefani 2000, 93, 96, 98; Nigdelis 2000, 143-144; Mann 2011, 129-134. 
imported institution, which called for a pseudonym of Roman colouring; the Roman colouring of the pseudonym was irrelevant to the gladiator's own ethnic or cultural descent, that could be Greek, Phrygian, Syriac, Jewish etc. ${ }^{16}$

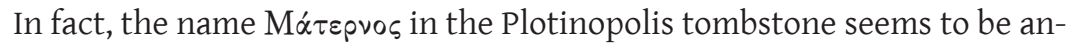
other gladiatorial pseudonym and the same also holds true for the (Greek-de-

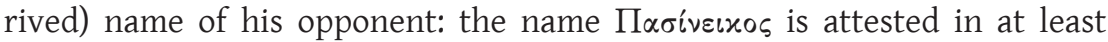
three inscriptions, making it a popular pseudonym for gladiators in the Eastern part of the Roman Empire. ${ }^{17}$ Maternos' real name could well have been a Greek one, ${ }^{18}$ he could just as well belong to one of the numerous ethnic groups of the Eastern Mediterranean, and he may have spoken no Latin at all despite his Latin pseudonym. ${ }^{19}$ It should be noted here that Greek writers of the Roman imperial period, despite the fact that they did not feel the slightest respect for this bloodthirsty Roman cultural import, regarded that gladiators themselves could be ethnic Greeks or culture-Greeks ${ }^{20}-$ a fact which calls for

16. On the realities latent behind the adoption of Latin-derived pseudonyms on the part of Greek-speaking gladiators, see the nuanced discussion of Mann 2011, 129-130, 132-133.

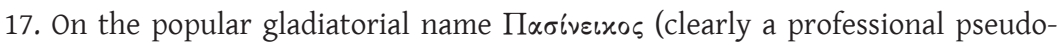
nym), see SEG 34, 40 [= Mann 2011, 185, no. 5] from Patrae; SEG 35, 722 [= Mann 2011, 194] from Beroia; Robert 1940, 228, no. 294, with mention also in 299 as a pseudonym [= IK Kyzikos 400; Pfuhl, Möbius 1979, no. 1268; Mann 2011, 249, no. 159 from Kyzikos]. On another attestation of Maternos as a gladiatorial pseudonym, see the Phrygian stone IGRR IV 1370 [= Robert 1940, 161, no. 136, with proposed supplement $\left.\delta \circ \tilde{v}(\lambda \circ)_{5}\right)$ ].

18. The pseudonym Maternos may well hide a Greek (original) name, which is not mentioned in the Plotinopolis stone (as it also happens with the real name of Pasineikos, also not mentioned on the same stone): for a parallel case, see the gladiatorial inscrip-

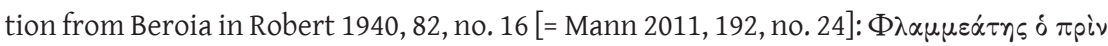
Z $\omega \sigma \iota \mu \varsigma \varsigma$ [Pseudonym: Flammeates (Latin-derived); original name: Zosimos (Greek)].

19. See Mann 2011, 132-133.

20. The most important manifestation of this fact is provided by a passage of

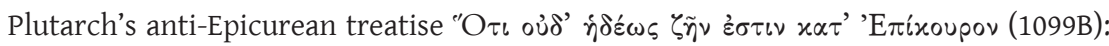

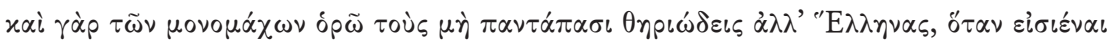

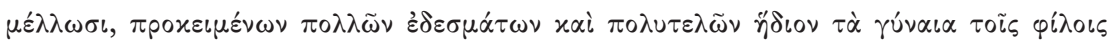

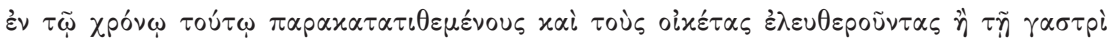

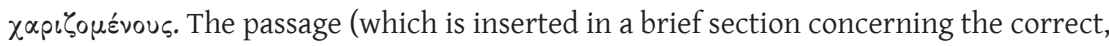


a more nuanced perception of real-life identities of gladiators, even of those among them who bore a Latin-derived pseudonym.

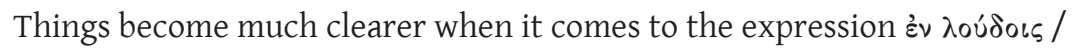

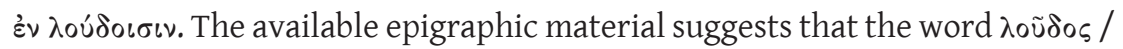
$\lambda \circ \tilde{\text { } \delta 0 เ ~ h a d ~ e n t e r e d ~ t h e ~ G r e e k ~ v o c a b u l a r y ~ s i n c e ~ a t ~ l e a s t ~ t h e ~} 2$ nd cent. AD and in cases where it is not always clear whether it means "gladiatorial games" or the "training camp for gladiators". ${ }^{21}$ For instance, the word $\lambda \circ \tilde{0} \delta \circ \varsigma$ under the meaning "gladiatorial games" is used in two gladiatorial inscriptions from Kos and Thyateira (in genitive singular). ${ }^{22}$ Further occurrences of the word

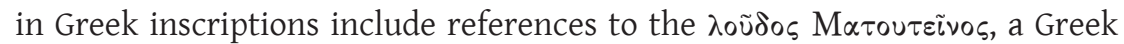
rendering of the ludus Matutinus, the training camp for gladiators and beasts at Rome; ${ }^{23}$ in two inscriptions there is also mention of the office हं $\pi i \tau \rho o \pi \circ s$ $\lambda \circ u \delta \delta \nu$ (the Greek translation of the Latin office procurator ludorum), where

that is: anti-Epicurean, practical philosophy of someone who faces the threat of extinction) introduces an interesting dichotomy between Greek and non-Greek gladiators. The non-Greek gladiators are regarded as collectively brutal ( $\pi \alpha \nu \tau \alpha \dot{\alpha} \pi \alpha \sigma \iota \theta_{\eta}$ they are not even discussed; the Greek ones, reminiscent (even in the last moments) of the Hellenic culture in which they were born and raised, will usually undertake actions benevolent towards the members of society connected to them (wives, house-slaves). The passage constitutes decisive evidence for the fact that, according to Plutarch, Greek-speaking gladiators were fundamentally unlucky, not fundamentally un-Greek: they could well retain their Greek cultural identity even after falling to the status of the

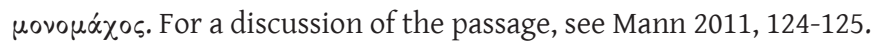

21. This ambivalence in the semantics of the word exists also in its (primordial) Latin-speaking environment: see Wiedemann 1992, 170, 185.

22. IGRR IV. 1072 [= Robert 1940, no. 186; Paton, Hicks 1891, 157, no. 138; Mainardis

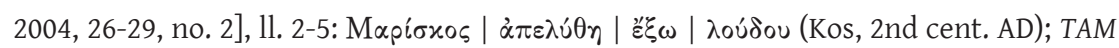

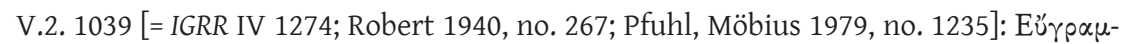

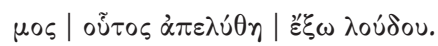

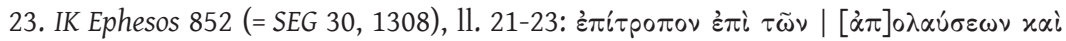

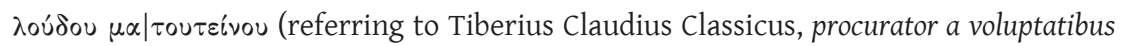

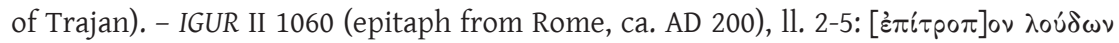

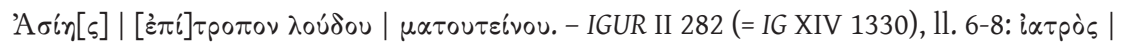

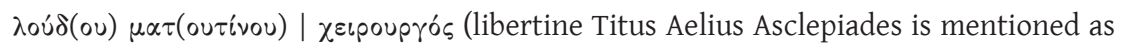
doctor and surgeon at the Ludus Matutinus at Rome). 
the word $\lambda_{0} \tilde{\delta} \delta \circ \iota$ is applied in genitive plural to designate training camps of gladiators. ${ }^{24}$

The above material demonstrates that the word seems to have been adapted to the Greek morphological system quite early; the fact that it is used in inscriptions concerned with doctors, higher officials (especially in honorific inscriptions commissioned by $\delta \tilde{\eta} \mu \circ \iota)$ or in the name of higher offices (e.g. $\varepsilon \pi i \tau \rho \circ \pi \circ \varsigma \lambda \circ u \delta(\omega v)$ demonstrates that it was a well-established word, not considered to belong to a lower sociolinguistic register. The fact that it remained morphologically adapted into the system of the Greek language, but nonetheless untranslated into Greek, should be viewed as a form of tacit recognition on the part of the Greek-speakers of the time, that gladiation was a fundamentally Roman cultural institution, whose terminology would rather remain untranslated (albeit morphologically adapted) into Greek. ${ }^{25}$

In fact, the Plotinopolis inscription of Maternos bears testimony to the adaptation of the word in the Greek linguistic use of the time. The word in the Plotinopolis inscription is given a poetic dative (even a $x \alpha \theta^{\prime} \varepsilon^{\prime} \lambda \xi_{L \nu}$ one) and it is clearly used to signify "gladiatorial games" - not the "training camp for gladiators" ${ }^{26}$ The Plotinopolis-stone contains no simple transcription of the

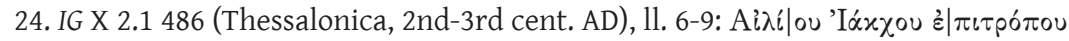

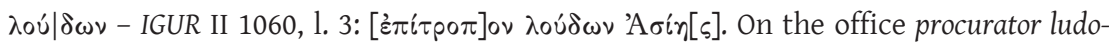
rum and its Greek equivalent ṡ $\pi i \tau \rho \circ \pi \circ \varsigma \lambda \circ u ́ \delta \omega \nu$, imperial offices responsible for the ludi (= training camps) and for the recruitment and the training of would-be gladiators, see discussion in Patrich 2011a, 22-23; Patrich 2011b, 272-274, with survey of older bibliography.

25. On the untranslated Latin loan words as an indication that the Greek-speaking world of the time viewed gladiation as a (not fully absorbable) Roman cultural import, see Mann 2011, 134. On the numerous Latin loan words in the Roman-era Greek vocabulary of gladiation, see Cameron 1931, 232-262; Robert 1940, 64-65; Carter 1999 passim; Mann 2011, 124-128 (with important observation on p.128 that the literary Greek prose of the period, influenced by the spirit of Atticism, avoids the use of Latin loan words popular in the vernacular Greek of the time, thus treating them as a linguistic "foreign body").

26. See also comment on the word in AnnÉpigr 2014 [2017] no. 1165, with important observation that the gladiator's armour as depicted in the relief corresponds to that of a secutor. 
word into Greek letters. The poetic declination of the word that it contains instead seems to demonstrate the outcome of a long process of adaptation, both morphological and semantical, of a Latin-derived word into a Greek-speaking environment operating under Roman rule.

Finally, it is important to note the many pieces of information on cultural, social, and linguistic issues that can be retrieved from this short text. ${ }^{27}$ Hopefully, further happy finds from late Roman Plotinopolis will provide us with more pieces of evidence on the linguistic and cultural history of the Greco-Roman ecumene during this most crucial period of transition, the 3rd and 4th centuries AD.

Dimitrios Papanikolaou philopappos@yahoo.gr

27. On the important new evidence that this inscription brings into light on the imperial cult and the prosopography of gladiatorial games in Plotinopolis, see the observations of Tsoka 2015, 88-89, 91-93. 


\section{Summary}

The paper is concerned with a new gladiatorial tombstone from Plotinopolis. The paper raises serious doubts on the text of the inscription offered by its initial editor (Tsoka 2015); it also pinpoints towards Sharankov's proposal (Année Épigraphique 2014 [2017] no. 1165, 493) as the only viable solution for the text of the inscription, citing also unnoticed parallel passages from ancient Greek inscriptions and texts as evidence substantiating the new reading of the stone (see nn. 7-9).

The paper expresses also disagreement over Tsoka's assertion that the words $\lambda \circ \tilde{\delta} \delta \circ \iota$ and Márepvos of the inscription are mere transcriptions into Greek letters of the Latin words ludi, Maternus - and that the name Márepvos implies Romanisation. It is argued that the Latin-derived name of a gladiator fighting in the Eastern (Greek-speaking) side of the Roman Empire is not a safe marker of Romanisation. This is demonstrated by the epigraphical evidence attesting to the habit of Greek-speaking gladiators to adopt professional pseudonyms, many of them ( $25 \%$ of all recorded cases) Latin-derived ones; the paper argues that the name Márepvos is simply a Latin-derived gladiatorial pseudonym. Plutarch's testimony further substantiates that gladiators could be ethnic Greeks or culture-Greeks (see n. 20). As far as the word $\lambda$ ov $\delta 0$ is concerned, the poetic declination of the word in the stone attests to the last stages in the adaptation of a Latin-derived word into a fundamentally Greek linguistic environment. The paper argues that the Latin-derived vocabulary of

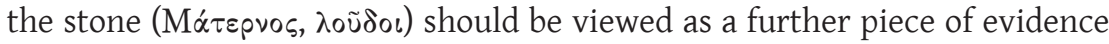
attesting to the recognition on the part of the Greek-speakers of the time, that gladiation was a fundamentally Roman cultural institution, a cultural import whose onomastics and terminology could rather remain untranslated. 


\section{Bibliography}

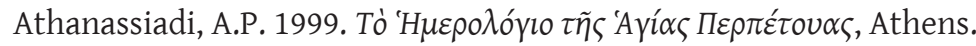

Autenrieth, G. 1895. A Homeric Dictionary, New York.

Cameron, A. 1931. "Latin Words in the Greek Inscriptions of Asia Minor", AJP 52, 232-262.

Cameron, A. 1973. Porphyrius the Charioteer, Oxford.

Carcopino, J. 1942. Aspects mystiques de la Rome païenne, Paris.

Carter, M. 1999. "A Doctor Secutorum and the Retiarius Draukos from Corinth", ZPE 126, 262-268.

Cougny, E. 1890. Epigrammatum Anthologia Palatina, cum Planudeis et Appendice Nova Epigrammatum veterum ex libris et marmoribus [...], vol. 3, Mainz-Paris.

Keil, J. 1953. "Vertreter der zweiten Sophistik in Ephesos”, JÖAI 40, 5-26.

Mainardis, F. 2004. Aliena Saxa, Rome.

Mann, Chr. 2011. 'Um keinen Kranz, um das Leben kämpfen wir'. Gladiatoren im Osten des Römischen Reiches und die Frage der Romanisierung, Berlin.

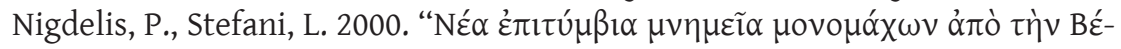

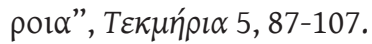

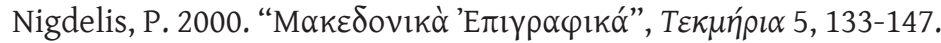

Paton, W.R., Hicks, E.L. 1891. The Inscriptions of Cos, Oxford.

Patrich, J. 2011a. "Caesarea in the Time of Eusebius", in: S. Inowlocki, C. Zamagni (eds.), Reconsidering Eusebius. Collected Papers on Literary, Historical, and Theological Issues (Supplements to Vigiliae Christianae 107), Leiden-Boston [Brill], 1-24.

Patrich, J. 2011b. Studies in the Archaeology and History of Caesarea Maritima: Caput Judaeae, Metropolis Palestinae (Ancient Judaism and Early Christianity 77), Leiden-Boston [Brill].

Pfuhl, E., Möbius, H. 1979. Die ostgriechischen Grabreliefs, vol. 2, Mainz.

Robert, L. 1940. Les Gladiateurs dans l'Orient grec, Paris.

Smyth, H.W. 1956. Greek Grammar, Cambridge, Mass.

Swain, S. 1996. Hellenism and Empire. Language, Classicism, and Power in the Greek World, AD 50-250, Oxford.

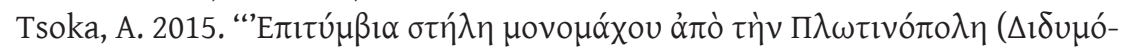

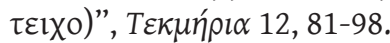

Weisshäupl, R. 1889. Die Grabgedichte der griechischen Anthologie, Vienna.

Whitmarsh, T. 2001. Greek Literature and the Roman Empire, Oxford.

Wiedemann, T. 1992. Emperors and Gladiators, London / New York. 
